\title{
ANALISIS ACTIVITY BASED COSTING SYSTEM DALAM PENENTUAN TARIF KAMAR PADA HOTEL GRAND BOUGENVILLE KOTA BENGKULU
}

\author{
Ida Ayu Made Er Meytha Gayatri, Indri Windasari \\ Program Studi Akuntansi Fakultas Ekonomi Universitas Dehasen Bengkulu \\ Cinta.gayatri@yahoo.co.id
}

\begin{abstract}
ABSTRAK
Ida Ayu Made Er Meytha Gayatri, Indri Windasari; Tujuan penelitian adalah untuk mengetahui activity based costing system dalam penentuan tarif kamar pada hotel Grand Bougenville Kota Bengkulu. Metode pengumpulan data dalam penelitian ini adalah dengan menggunakan metode dokumentasi dan wawancara. Metode analisis yang digunakan adalah metode analisis deskriptif kuantitatif, meneliti dan berusaha mendapatkan data yang akurat berupa angka-angka kemudian data yang diperoleh dihitung untuk mendapatkan jumlah tarif jasa kamar hotel tersebut.Terdapat perbedaan antara harga pokok kamar yang ditentukan oleh pihak manajemen hotel Grand Bougenville Kota Bengkulu dan dengan penerapan Activity Based Costing System. Hasil dari perhitungan harga pokok kamar dengan menggunakan Activity Based Costing Sytem yaitu, untuk kamar standard sebesar Rp. 172.249, superior sebesar Rp. 213.408, dan suite sebesar Rp. 331.182,-. Sedangkan harga pokok kamar berdasarkan perhitungan yang dilakukan oleh Hotel Grand Bougenvill kota Bengkulu diketahui untuk jenis kamar standard sebesar Rp. 136.651, superior sebesar Rp. 182.201, dan suite sebesar Rp. 273.302. Terdapat selisih perhitungan harga pokok kamar antara perhitungan Hotel Grand Bougenvill dengan metode Activity Based Costing Sytem yaitu standard sebesar Rp. 35.599,-- superior sebesar Rp. 31.297,-, dan suite sebesar Rp. 57.881. Perhitungan harga penjualan juga terdapat perbedaan antara perhitungan hotel Grand Bougenville Kota Bengkulu dengan hotel Grand Bougenville Kota Bengkulu dengan penambahan mark up sebesar 25\% maka harga jual yang ditetapkan sebesar standard sebesar Rp. 240.073,- superior sebesar Rp. 297.437,-, dan suite sebesar Rp. 461.585,. Terdapat selisih harga yang lebih rendah antara penerapan harga manajemen hotel dengan hasil perhitungan menggunakan Activity Based Coting Sysem yaitu, standard sebesar Rp. 240.073,- superior sebesar Rp. 297.437,-, dan suite sebesar Rp. 461.585,
\end{abstract}

\section{ABSTRACT}

Ida Ayu Made Er Meytha Gayatri, Indri Windasari; The aim of this study is to determine activity-based costing system in the determination of room rates on Grand Bougenville Hotel of Bengkulu City. Data collection method in this study used is documentation and interview. The method of analysis used is descriptive quantitative, trying to get accurate data in the form of numbers then the data is calculated to get the amount of hotel room rate. There is a difference between room cost which is determined by the management of Grand Bougenville Hotel of Bengkulu City and by applying activity based costing system. The calculation result of room cost by using activity-based costing system, namely for standard rooms of Rp 172.249,-- superior of Rp 182.201,- and suite of Rp 331.182,-. Meanwhile, room cost based on the calculations performed by Grand Bougenville Hotel of Bengkulu City known that for the standard room type of Rp 35.599,- superior $R p 31.297$ and suite of $R p$ 57.881. The calculation of the selling price is also different between hotel calculations with the addition of mark up by $25 \%$ then the sale price of standard is $R p$ 240.073 superior is $R p 297.437$ and suite is $R p$ 461.585. There is a lower price difference between the implementation of hotel management price and calculation result by using activity based costing system that is, standard Rp 240.073 superior Rp297.437 and suite Rp 461.585.

\section{Key Words: Hotel Room Rate, Activity Based Costing System}

\section{LATAR BELAKANG}

Semakin menjamurnya perusahaan jasa terutama yang bergerak di bidang pariwisata dan perhotelan, menyebabkan semakin ketatnya persaingan antar hotel. Keberhasilan dalam memenangkan persaingan tersebut ditentukan oleh beberapa hal antara lain quality, services dan price. Services adalah kuantitas atau ragam pelayanan yang disediakan pihak hotel terhadap pelanggannya misalnya fasilitas kolam renang, restoran, fitness centre, bar, dan lain sebagainya. Quality merupakan kualitas pelayanan terhadap konsumen, hal ini lebih menekankan pada kepuasan konsumen terhadap suatu jenis pelayanan. Kebersihan kolam yang selalu terjamin, rasa masakan yang sesuai dengan selera konsumen, alat-alat kebugaran yang lengkap dan berfungsi dengan baik, keramahan karyawan hotel merupakan contoh dari kualitas pelayanan yang disediakan pihak hotel terhadap tamu atau konsumennya. 
Selain quality dan services, price merupakan faktor yang sangat berpengaruh dalam perebutan hati para konsumen maupun calon konsumen. Price adalah jumlah nominal yang harus dibayarkan oleh konsumen atas pelayanan yang diberikan oleh pihak hotel atau penyedia jasa. Jika ada perbandingan antara beberapa hotel dengan quality dan services yang sama dalam hal penentuan harga dan mengabaikan faktor loyalitas konsumen terhadap produsen atau penyedia jasa, konsumen akan cenderung memilih hotel yang lebih murah (Hariadi, 2012).

Harga pokok mempunyai peranan yang sangat penting dalam menentukan harga jual produk. Penetapan biaya yang lebih tepat akan menghasilkan harga pokok produksi/jasa yang lebih akurat. Oleh karena itu, perusahaan harus benar- benar serius menangani harga pokok produksinya. Dalam perhitungan biaya produk untuk menentukan harga pokok produksi/ jasa masih banyak perusahaan yang menggunakan sistem tradisional metode full costing (Mulyadi, 2013).

Hotel Grand Bougenville Kota Bengkulu merupakan salah satu hotel yang ada di kota Bengkulu. Hotel ini memiliki jumlah kamar yang relatif banyak dengan tipe kamar seperti standard, superior dan suite. Di dalam pengoperasiannya, hotel ini dihadapkan dengan berbagai tipe kamar dan melalui berbagai tahap dalam penyelesaian produk/jasa sehingga muncul berbagai biaya diluar biaya bahan baku dan tenaga kerja langsung yang turut mendukung penyelesaian produk/jasa. Hal tersebut memerlukan adanya pengalokasian biaya secara akurat ke produk/jasa yang didasarkan pada sumber daya yang dikonsumsi sebagai akibat adanya berbagai aktivitas yang akhirnya akan menghasilkan perhitungan harga pokok produk/jasa.

Dengan melihat karakteristik spesifikasi jenis kamar, pelayanan, serta potensi persaingan dari kompetitor maka salah satu cara yang dilakukan Hotel Grand Bougenville kota Bengkulu dalam upaya meningkatkan efesiensi biayanya adalah dengan menentukan harga pokok produk/jasa secara tepat. Namun cara yang ditempuh oleh Hotel Grand Bougenville kota Bengkulu dalam penentuan harga pokoknya adalah cara tradisional. Jika dilihat dari penentuan harga pokok untuk penetapan tarif kamar dilihat masih kurang efektif karena belum adanya pengelompokan biaya yang terjadi.

\section{LANDASAN TEORI}

\section{Akuntansi Biaya}

Akuntansi biaya merupakan bagian yang integral dengan financial accounting. Akuntansi biaya adalah salah satu cabang akuntansi yang merupakan alat manajemen dalam memonitor dan merekam transakasi biaya secara sistematis, serta menyajikannya informasi biaya dalam bentuk laporan biaya.

Informasi ini membantu pihak perusahaan untuk menentukan sasaran laba perusahaan, menentukan target departemen yang membimbing perusahaan dan operasi kearah yang pencapaian akhir. Selain itu juga membentuk pihak perusahaan untuk mengawasi, mengungkap keberhasilan dan kegagalan menganalisa dan memutuskan untuk mengadakan penyesuaian serta perbaikan agar tercapainya tujuan yang telah ditetapkan.

Menurut Supriyono (2002), akuntansi biaya adalah "salah satu cabang akuntansi yang merupakan alat manajemen dalam memonitor dan merekam transaksi biaya secara sistematis, serta menyajikan informasi dalam bentuk laporan biaya".

Dari pendapat tersebut dapat disimpulkan bahwa akuntansi biaya adalah proses pencatatan, peringkasan dan penyajian biaya dalam pembuatan produk dan jasa oleh perusahaan sehingga dapat menafsirkan hasil produksi tersebut dan menyajikannya dalam bentuk laporan biaya. Manfaat akuntansi biaya adalah menyediakan salah satu informasi yang diperlukan manajemen dalam mengelola perusahaan yaitu informasi biaya yang bermanfaat untuk:

1. Perencanaan dan pengendalian biaya

2. Penentuan harga pokok produk

3. Pengambilan keputusan oleh manajemen

\section{Biaya}

Menurut Mulyadi (2014:13) biaya digolongkan sebagai berikut:

1. Menurut fungsi pokok dalam perusahaan, biaya dapat digolongkan menjadi tiga kelompok, yaitu:

a. Biaya Produksi, semua biaya yang berhubungan dengan fungsi produksi atau kegiatan pengolahan bahan baku menjadi barang jadi. Biaya produksi dapat digolongkan kedalam biaya bahan baku langsung, biaya tenaga kerja langsung, dan biaya overhead pabrik.

b. Biaya Pemasaran, adalah biaya-biaya yang terjadi untuk melaksanakan kegiatan pemasaran produk, contohnya biaya iklan, biaya promosi, biaya sampel, dan lain - lain.

c. Biaya administrasi dan umum, yaitu biaya-biaya untuk mengkoordinasikan kegiatan-kegiatan produksi dan pemasaran produk.

2. Menurut hubungan biaya dengan sesuatu yang dibiayai ada dua golongan, yaitu: 
a. Biaya langsung (direct cost), merupakan biaya yang terjadi dimana penyebab satu-satunya adalah karena ada sesuatu yang harus dibiayai. Dalam kaitannya dengan produk, biaya langsung terdiri dari biaya bahan baku dan biaya tenaga kerja langsung.

b. Biaya tidak langsung (indirect cost), biaya yang terjadi tidak hanya disebabkan oleh sesuatu yang dibiayai, dalam hubungannya dengan produk, biaya tidak langsung dikenal dengan biaya overhead pabrik.

3. Menurut perilaku dalam kaitannya dengan perubahan volume kegiatan, biaya dibagi menjadi empat, yaitu:

a. Biaya tetap (fixed cost), biaya yang jumlahnya tetap konstan tidak dipengaruhi perubahan volume kegiatan atau aktivitas sampai tingkat kegiatan tertentu.

b. Biaya variabel (variable cost), biaya yang jumlah totalnya berubah secara sebanding dengan perubahan volume kegiatan atau aktivitas.

c. Biaya semi variabel, biaya yang jumlah totalnya berubah tidak sebanding dengan perubahan volume kegiatan biaya semi variabel mengandung unsur biaya tetap dan biaya variabel.

d. Biaya semi fixed, biaya yang tetap untuk tingkat volume kegiatan tertentu dan berubah dengan jumlah yang konstan pada volume produksi tertentu.

\section{Metode Harga Pokok Activity Based Costing}

Menurut Dewi dan Kristanto (2013) Sistem Activity Based Costing (ABC) adalah suatu system perhitungan biaya dimana tempat penampungan biaya overhead pabrik yang jumlahnya lebih dari satu, dialokasikan menggunakan dasar yang memasukan suatu atau lebih faktor yang tidak berkaitan dengan volume.

Menurut Mulyadi (2005) activity based cost system merupakan salah satu wujud pelepasan akuntansi manajemen dari dominasi akuntansi keuangan. Sistem ini dirancang atas dasar landasan pikiran bahwa cost object memerlkukan aktivitas dan aktivitas mengkonsumsi sumber daya. Berdasarkan pikiran ini dibanguan keyakinan dasar bahwa biaya ada penyebabnya dan penyebab biaya dapat dikelola. Adapun hakikat dari activity based cost system seperti pada gambar berikut :

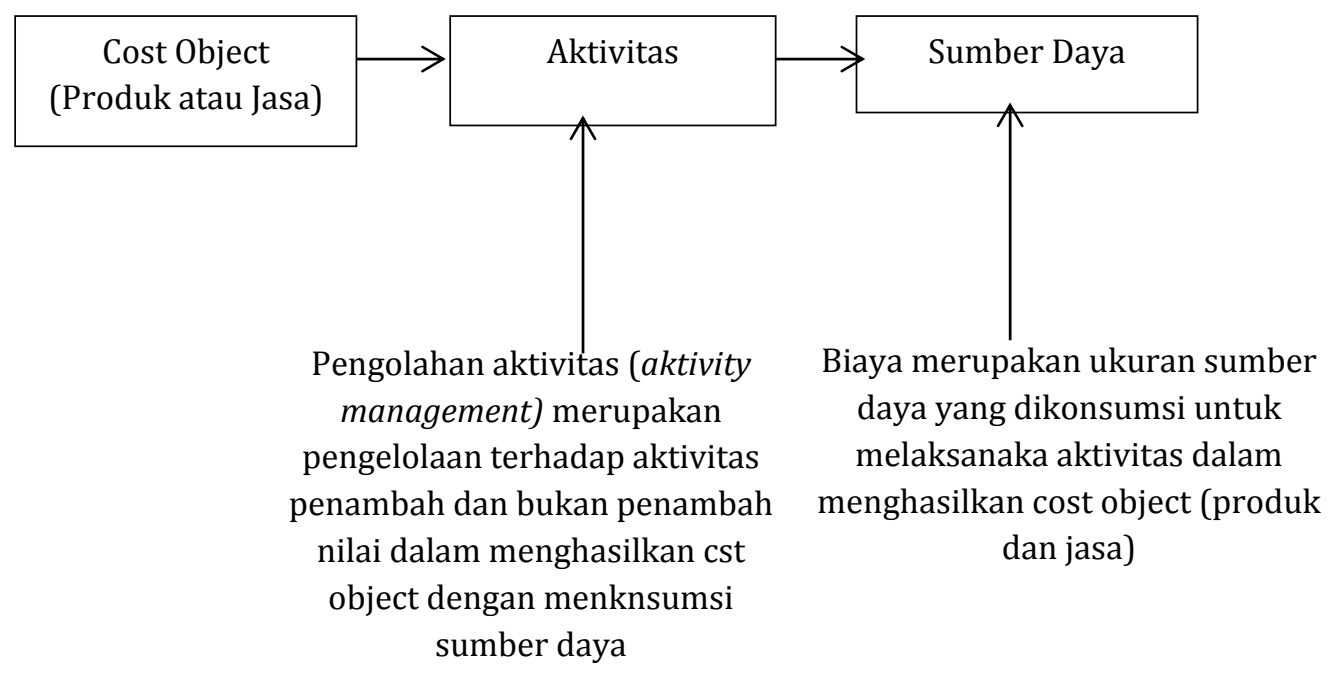

Sumber : Mulyadi (2005)

Gambar 1. Hakekat Activity Based Cost System

Dari definisi-definisi diatas penulis dapat menarik kesimpulan bahwa sistem ABC merupakan suatu metode mengenai sistem perencanaan biaya yang dikembangkan untuk mengantisipasi kelemahankelemahan yang terdapat dalam sistem akuntansi biaya konvensional. Yang menjadi pokok perhatian $\mathrm{ABC}$ adalah aktivitas-aktivitas perusahaan, dengan penelusuran biaya untuk menghitung harga pokok produk atau jasa, yaitu aktivitas yang mengkonsumsi sumber daya dan produk atau jasa yang mengkonsumsi aktivitas. Dengan demikian sistem ABC memudahkan perhitungan harga pokok objek biaya yang akurat sehingga mengurangi distorsi pada sistem biaya konvensional dan meningkatkan efektivitas pengambilan keputusan pihak manajemen.

Activity Based Costing menyediakan informasi perihal aktivitas - aktivitas dan sumber daya yang dibutuhkan untuk melaksanakan aktivitas - aktivitas tersebut. Aktivitas adalah setiap kejadian atau transaksi yang merupakan pemicu biaya (cost driver) yakni, bertindak sebagai faktor penyebab dalam 
pengeluaran biaya dalam organisasi. Aktivitas - aktivitas ini menjadi titik perhimpunan biaya. Dalam sistem $A B C$, biaya ditelusur ke aktivitas dan kemudian ke produk. Sistem $A B C$ mengasumsikan bahwa aktivitas-aktivitaslah yang mengkonsumsi sumber daya dan bukannya produk.

Desain $A B C$ difokuskan pada kegiatan, yaitu apa yang dilakukan oleh tenaga kerja dan peralatan untuk memenuhi kebutuhan pelanggan. Kegiatan adalah segala sesuatu yang mengkonsumsi sumber daya perusahaan. Dengan memusatkan perhatian pada kegiatan dan bukannya departemen atau fungsi, maka sistem $A B C$ akan dapat menjadi media untuk memahami, memanajemeni, dan memperbaiki suatu usaha. Ada dua asumsi penting yang mendasari Metode Activity Based Costing, yaitu (Anton, 2012:132) :

1. Aktivitas - aktivitas yang menyebabkan timbulnya biaya

Metode Activity Based Costing bahwa sumber daya pembantu atau sumber daya tidak langsung menyediakan kemampuannya untuk melaksanakan kegiatannya bukan hanya sekedar penyebab timbulnya biaya.

2. Produk atau pelanggan jasa

Produk menyebabkan timbulnya permintaan atas dasar aktivitas untuk membuat produk atau jasa yang diperlukan berbagai kegiatan yang menimbulkan sumber daya untuk melaksanakan aktivitas tersebut.

\section{Tahap Pengolahan Data Dalam Activity Based Costing System}

Menurut Hansen dan Mowen (2009:175) proses penerapan Activity Based Costing System (ABC System ) untuk menentukan harga pokok produksi dapat dibagi menjadi dua prosedur, yaitu:

a. Prosedur Tahap Pertama

Prosedur tahap pertama penentuan harga pokok produksi berdasarkan ABC System terdiri dari empat langkah, yaitu:

1. Mengidentifikasi Aktivitas

Langkah pertama untuk menerapkan $\mathrm{ABC}$ System adalah mengidentifikasi aktivitas yang akan menjadi dasar sistem tersebut.

2. Mengklasifikasi Berbagai Aktivitas

Mengklasifikasikan aktivitas yang akan menjadi dasar sistem tersebut. Berbagai aktivitas diklasifikasikan dalam beberapa kelompok yang mempunyai suatu interprestasi yang mudah dan jelas serta cocok dengan segmen-segmen proses produksi yang dapat dikelola untuk menghasilkan produk atau jasa. Cara untuk memahami aktivitas dan bagaimana aktivitas tersebut digabungkan disusun dalam empat tingkat, yaitu : unit level activities, batch level activities, product level activities, dan facility level activities.

3. Mengidentifikasi Cost Driver

Mengidentifikasi cost driver dari aktivitas-aktivitas yang telah diidentifikasi dan diklasifikasikan. Langkah selanjutnya adalah mengelompokkan jenis-jenis biaya yang sejenis atau homogen. Syarat biaya homogen adalah aktivitas-aktivitas harus secara logis berkaitan dan mempunyai rasio konsumsi yang sama untuk semua produk.

4. Menentuan Tarif Kelompok (Pool Rate)

Tarif kelompok adalah tarif biaya overhead perunit cost driver yang dihitung untuk suatu kelompok aktivitas Tarif kelompok dapat dihitung dengan rumus sebagai berikut:

b. Prosedur Tahap Kedua

\section{Tarlf perunit cost driver $\frac{\text { Jumlah aktivitas }}{\text { cost driver" }}$}

Setiap kelompok biaya overhead dibebankan kepada produk. Hal ini dilakukan dengan menggunakan tarif yang telah dihitung sebelumnya dan nilai sumber daya aktivitas yang dikonsumsi setiap jenis produk. Dengan demikian, overhead yang dibebankan dari setiap kelompok biaya kepada setiap jenis produk dapat dihitung sebagai berikut:

BOP dibebankan $=$ Tarif kelompok $\times$ Unit Cost Driver yang digunakan

Setelah menentukan tarif per unit cost driver dan membebankan biaya ke produk dan jasa menggunakan tarif cost driver selanjutnya yaitu:

1. Menyusun perhitungan barga pook produksi menurut Activity Based Costing System.

2. Membandingkan perhitungan harga pokok menurut prusahaan dan menurut Activity Based Costing System.

3. Menarik kesimpulan dari perbandingan perhitungan yang terjadi. 


\section{KERANGKA ANALISIS}

Biaya jasa pada Hotel Grand Bougenville berdasarkan aktivitas terdiri dari :
1) Penginapan
2) Loundry
3) Makan pagi
4) Pemberian gaji
5) Pemeliharaan dan perawatan

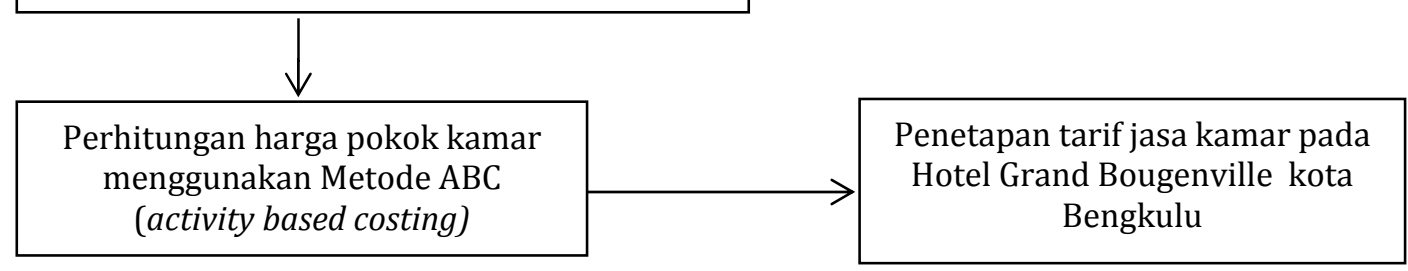

Gambar 2. Kerangka Analisis

\section{METODOLOGI}

\section{Jenis dan Metode Pengumpulan Data}

Penelitian ini merupakan penelitian deskriptif kuantitatif, Menurut Sugiyono (2013 : 206), deskriptif kuantitatif yaitu statistik yang digunakan dengan cara mendepenelitiankan atau menggambarkan data yang telah terkumpul sebagaimana adanya tanpa bermaksud membuat kesimpulan yang berlaku untuk umum atau generalisasi yaitu penulis meneliti data-data yang berhubungan dengan elemen-elemen harga pokok produk yang dianggarkan dan data-data yang diperoleh dibahas dengan melakukan perhitungan harga pokok produksi yang sesungguhnya

Metode pengumpulan data pada penelitian ini adalah sebagai berikut:

1. Metode dokumentasi, menurut Sugiyono (2013:145) yaitu metode pengumpulan data yang penyediaannya ditujukan pada penguraian dan penjelasan, melalui sumber-sumber dokumen yang ada di Hotel Grand Bougenville Kota Bengkulu.

2. Wawancara (Interview) tidak terstruktur. Dalam hal ini wawancara dilakukan dengan pimpinan dan karyawan yang berhubungan dengan penelitian.

\section{Metode Analisis}

Teknik analisis yang digunakan pada penelitian ini adalah metode analisis deskriptif kuantitatif, meneliti dan berusaha mendapatkan data yang akurat berupa angka-angka kemudian data yang diperoleh dihitung untuk mendapatkan jumlah tarif jasa kamar hotel tersebut. Adapun langkah-langkah analisis data yang dilakukan adalah:

1. Mencantumkan harga pokok kamar hotel menurut Hotel Grand Bougenvill

2. Melakukan perhitungan harga pokok kamar hotel menggunakan Activity-Based Costing System. Langkah-langkah penerapan Activity Based Costing System dalam penelitian ini sebagai berikut:

a. Mengidentifikasikan aktivitas, seperti :
1) Penginapan
2) Loundry
3) Makan pagi
4) Pemberian gaji
5) Pemeliharaan dan perawatan

b. Mengklasifikasikan biaya berdasarkan aktivitas ke dalam berbagai level aktivitas. Dengan cara menentukan level atau tingkat dari aktivitas seperti unit level, produk level, facility level.

c. Mengidentifikasi cost driver yang dibuat berdasarkan cost pool peraktivitas, seperti :

1) Aktivitas penginapan untuk cost driver dapat berdasarkan jumlah tamu yang menginap dan jumlah kamar terjual dimasukan kedalam cost poll 1

2) Aktivitas laundry meliputi pencucian handuk, seprai dan selimut dimasukan kedalam cost poll1

3) Aktivitas pemasaran meliputi biaya koran dan biaya pemasaran dimasukan kedalam cost poll 2

d. Menentukan tarif per unit cost driver

Cost driver akan dikelompokan berdasarkan aktivitas seperti :

1) Penginapan terdiri dari biaya quest supplies, cleaning supplies, decoration

2) Loundry seperti loundry dan dry cleaning

Untuk menentukan tarif per unit dihitung dengan rumus: 


\section{Tarlf perundt cost driver" $\frac{\text { Jumlah alstivitae }}{\text { cost driwer }}$}

e. Membebankan biaya ke produk dan jasa dengan menggunakan tarif cost driver dan ukuran aktivitas. Pembebanan biaya overhead dari tiap aktivitas ke setiap kamar dihitung dengan rumus sebagai berikut:

BOP dibebankan $=$ Tarif kelompok $\times$ Unit Cost Driver yang digunakan

f. Menyusun perhitungan barga pokok kamar hotel menurut Activity Based Costing System.

3. Menetapkan tarif kamar pada Hotel Grand Bougenvill. Sedangkan dalam penentuan tarif kamar atau harga jual kamar, metode yang digunakan adalah metode harga jual harga normal (normal pricing), adapun rumus dalam penentuan normal pricing menurut Mulyadi (2007:348) adalah:

Harga Jual $=$ Total harga pokok produksi $+\%$ Laba Yang Diharapkan

Adapun laba yang diharapkan ditetapkan sebesar $25 \%$ dari total taksiran harga pokok

\section{HASIL PENELITIAN DAN PEMBAHASAN}

\section{Perhitungan Harga Pokok Kamar Hotel Menggunakan Activity Based Costing System (ABC System)}

Untuk menentukan harga pokok kamar pada Hotel Grand Bougenville dengan menggunakan metode activity based costing dapat dilakukan dengan langkah-langkah sebagai berikut:

\section{a. Pengidentifikasian Aktivitas}

Untuk pengindentifikasian aktivitas yang ada pada Hotel Grand Bougenville akan dipisahkan berdasarkan aktivitas yang dilakukan pada hotel, seperti pada tabel berikut:

Tabel 1. Daftar Aktivitas

\begin{tabular}{|c|l|}
\hline No & \multicolumn{1}{|c|}{ Aktivitas } \\
\hline 1 & Penginapan \\
\hline 2 & Laundry \\
\hline 3 & Pemberian Makan Pagi \\
\hline 4 & Keadministrasian \\
\hline 5 & Penggunaan Energi \\
\hline 6 & Pemasran \\
\hline 7 & Pemeliharaan dan Perawatan \\
\hline 8 & Penggajian \\
\hline
\end{tabular}

Sumber : Data Diolah, 2017

\section{b. Pengklasifikasian Biaya Berdasar Aktivitas ke dalam Berbagai Level Aktivitas}

Langkah selanjutnya adalah pengklasifikasian biaya berdasarkan ativitas ke dalam berbagai level aktivitas, seperti unit level, product level dan facility level. Adapun pengklasifikasian aktivitas dapat dilihat pada tabel 10.

Tabel 2. Klasifikasi Aktivitas

\begin{tabular}{|c|l|l|}
\hline No & \multicolumn{1}{|c|}{ Aktivitas } & \multicolumn{1}{|c|}{ Level Aktivitas } \\
\hline 1 & Penginapan & Unit Level \\
\hline 2 & Laundry & Unit Level \\
\hline 3 & Pemberian Makan Pagi & Unit Level \\
\hline 4 & Keadministrasian & Unit Level \\
\hline 5 & Penggunaan Energi & Unit Level \\
\hline 6 & Pemasran & Product Level \\
\hline 7 & Pemeliharaan dan Perawatan & Facility Level \\
\hline 8 & Penggajian & Unit Level \\
\hline
\end{tabular}

Sumber : Data Diolah, 2017

\section{c. Pengidentifikasian Cost Driver}

Langkah selanjutnya adalah pengidentifikasin cost driver dengan tujuan adanya pembagian biaya berdasarkan cost driver sebagai berikut :

1) Aktivitas penginapan untuk cost driver dilakukan berdasarkan jumlah kamar yang terjual.

2) Aktivitas laundry meliputi pencucian handuk, seprai dan selimut. Untuk cost driver dapat berdasarkan jumlah kamar kamar terjual karena pencucian tersebut akan dilakukan setelah kamar terjual. 
3) Aktivitas penggunaan energi merupakan energi yang digunakan seperti listrik dan gas. Untuk cost driver dapat berdasarkan jumlah kamar terjual.

4) Aktivitas keadministrasian terdiri dari kegiatan yang berhubungan dengan administrasi seperti printing, foto copy dan kebersihan operasional hotel yang berhubungan dengan kamar hotel, untuk cost driver dapat berdasarkan jumlah kamar terjual.

5) Aktivitas pemberian makan pagi merupakan kebijkan yang diambil oleh hotel untuk setiap tamu yang menginap akan diberikan makan pagi dengan harga Rp. 20.000,-/orang. Untuk cost driver dapat berdasarkan jumlah tamu yang menginap.

6) Aktivitas pemasaran merupakan aktivitas yang dilakukan oleh hotel untuk pemasaran hotelnya, pada Hotel Grand Bougenville aktivitas pemasran dilakukan melalui surat kabar, cost driver yang tepat adalah jumlah kamar tersedia.

7) Aktivitas pemeliharaan dan perawatan meliputi pemeliharaan dan perawatan peralatan hotel dan fasilitas hotel. Cost driver dapat berdasarkan jumlah luas kamar tersedia

9) Aktivitas penggajian untuk cost driver yang tepat berdasarkan jumlah jam kerja.

Pengidentifikasian ini dimaksudkan dalam penentuan kelompok aktivitas dan cost driver nya. Pengelompokan tersebut dapat dilihat pada tabel berikut:

Tabel 3. Penentuan Cost Driver

\begin{tabular}{|c|l|l|l|}
\hline No & \multicolumn{1}{|c|}{ Aktivitas } & \multicolumn{1}{|c|}{ Level Aktivitas } & \multicolumn{1}{c|}{ Cost Driver } \\
\hline 1 & Penginapan & Unit Level & Jumlah kamar terjual \\
\hline 2 & Laundry & Unit Level & Jumlah kamar terjual \\
\hline 3 & Pemberian Makan Pagi & Unit Level & Jumlah tamu menginap \\
\hline 4 & Keadministrasian & Unit Level & Jumlah kamar terjual \\
\hline 5 & Penggunaan Energi & Unit Level & Jumlah kamar terjual \\
\hline 6 & Pemasaran & Product Level & Jumlah kamar tersedia \\
\hline 7 & Pemeliharaan dan Perawatan & Facility Level & Luas lantai \\
\hline 8 & Penggajian & Unit Level & Jumlah jam kerja \\
\hline
\end{tabular}

Sumber : Data Diolah, 2017

Berdasarkan tabel terdapat beberapa aktivitas yang memiliki rasio konsumsi dan level aktivitas yang sama sehingga dapat dikelompokkan dalam biaya homogen. Biaya dari aktivitas yang sudah dikelompokkan tersebut dijumlahkan untuk menentukan kelompok-kelompok biaya homogen. Setelah pengelompokkan aktivitas dilakukan maka selanjutnya biaya dari aktivitas yang sudah dikelompokkan tersebut dijumlah.

Perhitungan biaya per aktivitas cost pool I yang telah dikelompokkan tersebut dapat kita lihat dari tabel berikut:

Tabel 4. Rincian Biaya Per Aktivitas Cost Pool I

\begin{tabular}{|l|r|r|}
\hline \multicolumn{1}{|c|}{ Jenis Aktivitas } & \multicolumn{1}{c|}{ Cost Driver } & \multicolumn{1}{c|}{ Biaya } \\
\hline Penginapan & Jumlah kamar terjual & 51.355 .833 \\
\hline - Guest Supplies & & 3.425 .861 \\
\hline - Cleaning Supplies & & 536.313 \\
\hline - Decoration & & 1.810 .000 \\
\hline - Uniform (seragam) & Jumlah kamar terjual & 63.598 .100 \\
\hline Loundry & & \\
\hline $\begin{array}{l}\text { - Loundry \& Dry } \\
\text { Cleaning }\end{array}$ & Jumlah kamar terjual & \\
\hline Penggunaan Energi & & 4.340 .000 \\
\hline - Electricity & & 414.247 \\
\hline - Fuel \& gas & Jumlah kamar terjual & 19.758 .050 \\
\hline Keadministrasian & & $\mathbf{1 6 9 . 6 5 6 . 3 6 8}$ \\
\hline - Printing, Stationary, Ph Copy, Post & \\
\hline - Kebersihan Operasional Hotel & & \\
\hline \multicolumn{1}{|c|}{ Total } & \\
\hline
\end{tabular}

Sumber : Data Diolah, 2017

Tabel 5. Rincin Biaya per Aktivitas Cost Pool II

\begin{tabular}{|l|c|c|}
\hline Jenis Aktivitas & Cost Driver & Biaya \\
\hline Pemberian Makan Pagi & & \\
\hline Breakfast buffet 2.784 x Rp. 20.000 & Jumlah tamu menginap & 55.680 .000 \\
\hline \multicolumn{2}{|c|}{ Total } & $\mathbf{5 5 . 6 8 0 . 0 0 0}$ \\
\hline
\end{tabular}

Sumber : Data Diolah, 2017 
Tabel 6. Rincian Biaya per Aktivitas Cost Pool III

\begin{tabular}{|l|c|c|}
\hline \multicolumn{1}{|c|}{ Jenis Aktivitas } & Cost Driver & Biaya \\
\hline Pemasaran & Jumlah kamar tersedia & \\
\hline - Newspaper & & 8.060 .500 \\
\hline \multicolumn{2}{|c|}{ Total } & $\mathbf{8 . 0 6 0 . 5 0 0}$ \\
\hline
\end{tabular}

Sumber : Data Diolah, 201

Tabel 7. Rincian Biaya per Aktivitas Cost Pool IV

\begin{tabular}{|c|c|c|}
\hline Jenis Aktivitas & Cost Driver & Biaya \\
\hline Pemeliharaan dan Perawatan & Jumlah luas lantai & \\
\hline - Reservation Expenses & & 14.753 .481 \\
\hline \multicolumn{2}{|c|}{ Total } & $\mathbf{1 4 . 7 5 3 . 4 8 1}$ \\
\hline
\end{tabular}

Sumber : Data Diolah, 2017

Tabel 8. Rincian Biaya per Aktivitas Cost Pool V

\begin{tabular}{|l|c|c|}
\hline \multicolumn{1}{|c|}{ Jenis Aktivitas } & Cost Driver & Biaya \\
\hline Penggajian & Jumlah jam kerja & \\
\hline- Salaries \& Wages & & 88.224 .667 \\
\hline- Transport & & 429.000 \\
\hline- THR / Bonus / Incentive & & 4.150 .000 \\
\hline- Jamsostek / Askes & & 4.580 .935 \\
\hline- Daily Worker & & 3.949 .233 \\
\hline- Employee Meals & 250.000 \\
\hline- Medical \& Hospitalization Expenses & $\mathbf{1 4 3 . 9 4 8 . 8 3 5}$ \\
\hline \multicolumn{2}{|c|}{ Total } & \\
\hline
\end{tabular}

Sumber : Data Diolah, 2017

Tabel 9. Pemakaian Cost driver Tahun 2016

\begin{tabular}{|c|c|c|}
\hline No & Cost Driver & Jumlah \\
\hline \multirow[t]{2}{*}{1} & $\begin{array}{l}\text { Jumlah Kamar Terjual } \\
\text { Standard } \\
\text { Superior } \\
\text { Suit }\end{array}$ & $\begin{array}{c}1.255 \\
604 \\
142\end{array}$ \\
\hline & Total & 2.001 \\
\hline \multirow[t]{5}{*}{2} & Jumlah Tamu Menginap & \\
\hline & Standard & 1.589 \\
\hline & Superior & 898 \\
\hline & Suit & 297 \\
\hline & Total & 2.784 \\
\hline \multirow[t]{5}{*}{3} & Jumlah Kamar Tersedia & \\
\hline & Standard & 5.110 \\
\hline & Superior & 2.920 \\
\hline & Suit & 730 \\
\hline & Total & 8.760 \\
\hline \multirow[t]{5}{*}{4} & Jumlah Luas Lantai & \\
\hline & Standard & 336 \\
\hline & Superior & 288 \\
\hline & Suit & 84 \\
\hline & Total & 708 \\
\hline \multirow[t]{5}{*}{5} & Jumlah Jam Kerja & \\
\hline & Standard & 12.101 \\
\hline & Superior & 9.318 \\
\hline & Suit & 4.861 \\
\hline & Total & 26.280 \\
\hline
\end{tabular}

Sumber : Data Diolah, 2017 


\section{d. Penentuan Tarif Kelompok per Unit}

Setelah pengidentifikasian Cost Driver, langkah selanjutnya menentukan cost pool rate dengan cost driver. Tarif kelompok merrupakan tarif biaya overhead per unit cost driver yang di hitung untuk sekelompok aktivitas. Hal ini dapat dihitung dengan rumus sebagai berikut:

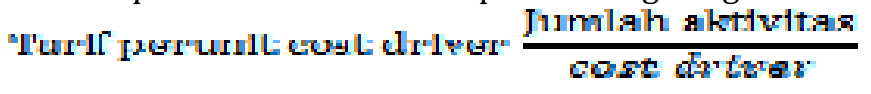

Tabel 10. Tarif Per unit Cost Driver

\begin{tabular}{|c|c|c|c|}
\hline \multirow{2}{*}{ Cost Pool } & Tarif Cost Pool & Cost Driver & Tarif/Unit \\
\cline { 2 - 4 } & 1 & 2 & $1: 2$ \\
\hline Cost Pool I & 169.656 .368 & 2.001 & 84.786 \\
\hline Cost Pool II & 55.680 .000 & 2.784 & 20.000 \\
\hline Cost Pool III & 8.060 .500 & 8.760 & 920 \\
\hline Cost Pool IV & 14.753 .481 & 708 & 20.838 \\
\hline Cost Pool V & 143.948 .835 & 26.280 & 5.478 \\
\hline
\end{tabular}

Sumber : Data Diolah, 2017

e. Pembebanan Biaya ke Produk dan Jasa dengan Menggunakan Tarif Cost Driver dan Ukuran Aktivitas.

Langkah selanjutnya adalah pembebanan biaya ke produk dan jasa dengan menggunakan tarif cost driver dan ukuran aktivitas, adapun rumus yang digunakan untuk pembenanan BOP adalah sebagai berikut :

BOP dibebankan $=$ Tarif kelompok $\times$ Unit Cost Driver yang digunakan

Tabel 11. Harga Pokok Kamar per Hari Tipe Standard

\begin{tabular}{|c|c|r|}
\hline Tarif Cost Poll & Cost Driver & \multicolumn{1}{c|}{ Jumlah } \\
\hline 84.786 & 1.255 & 106.406 .168 \\
\hline 20.000 & 1.589 & 31.780 .000 \\
\hline 920 & 5.110 & 4.701 .958 \\
\hline 20.838 & 336 & 7.001 .652 \\
\hline 5.478 & 12.101 & 66.283 .290 \\
\hline Total Biaya & & 216.173 .068 \\
\hline Jumlah kamar terjual & & 1.255 \\
\hline Harga pokok kamar standar & & 172.249 \\
\hline
\end{tabular}

Sumber : Data Diolah, 2017

Tabel 12. Harga Pokok Kamar per Hari Tipe Superior

\begin{tabular}{|c|c|r|}
\hline Tarif Cost Poll & Cost Driver & \multicolumn{1}{|c|}{ Jumlah } \\
\hline 84.786 & 604 & 51.210 .618 \\
\hline 20.000 & 898 & 17.960 .000 \\
\hline 920 & 2.920 & 2.686 .833 \\
\hline 20.838 & 288 & 6.001 .416 \\
\hline 5.478 & 9.318 & 51.039 .393 \\
\hline Total Biaya & & 128.898 .260 \\
\hline Jumlah kamar terjual & & 604 \\
\hline Harga pokok kamar standar & & 213.408 \\
\hline
\end{tabular}

Sumber : Data Diolah, 2017 
Tabel 13. Harga Pokok Kamar per Hari Tipe Suite

\begin{tabular}{|c|c|r|}
\hline Tarif Cost Poll & Cost Driver & \multicolumn{1}{|c|}{ Jumlah } \\
\hline 84.786 & 142 & 12.039 .582 \\
\hline 20.000 & 297 & 5.940 .000 \\
\hline 920 & 730 & 671.708 \\
\hline 20.838 & 84 & 1.750 .413 \\
\hline 5.478 & 4.861 & 26.626 .153 \\
\hline Total Biaya & & 47.027 .856 \\
\hline Jumlah kamar terjual & & 142 \\
\hline Harga pokok kamar standar & & 331.182 \\
\hline
\end{tabular}

Sumber : Data Diolah, 2017

Berdasarkan hasil penelitian maka dapat diketahui bahwa terdapat perbedaan jumlah harga pokok dalam penentuan tarif kamar antara perhitungan yang dilakukan oleh Hotel Grand Bougenvill kota Bengkulu dengan perhitungan harga pokok tarif kamar dengan metode Activity-Based Costing System. Adapun perbedaannya dapat dilihat pada tabel berikut ini.

Tabel 14. Perbandingan Perhitungan Tarif Kamar dan Harga Jual Menurut Hotel Grand Bougenvill Kota Bengkulu Dengan Metode Activity-Based Costing System

\begin{tabular}{|c|c|c|c|c|c|c|}
\hline \multirow{2}{*}{ Jenis } & \multicolumn{2}{|c|}{ Harga Pokok Tarif Kamar } & Harga Jual \\
\cline { 2 - 6 } & Hotel & Teori & Selisih & Hotel & Teori & Selisih \\
\hline Standard & 136.651 & 172.249 & -35.599 & 300.000 & 240.073 & 59.927 \\
\hline Superior & 182.201 & 213.408 & -31.207 & 400.000 & 297.437 & 102.563 \\
\hline Suite & 273.302 & 331.182 & -57.881 & 600.000 & 461.585 & 138.415 \\
\hline
\end{tabular}

Sumber: Data diolah, 2017

Berdasarkan tabel di atas dapat dilihat bahwa adanya perbedaan perhitungan harga pokok kamar antara perhitungan yang dilakukan oleh Hotel Grand Bougenvill kota Bengkulu dengan menggunakan Activity Based Costing System. Harga pokok kamar berdasarkan perhitungan yang dilakukan oleh Hotel Grand Bougenvill kota Bengkulu diketahui untuk jenis kamar standard sebesar Rp. 136.651, superior sebesar Rp. 182.201, dan suite sebesar Rp. 273.302,-. Sedangkan jika menggunakan metode Activity Based Costing System dapat diketahui besarnya harga pokok kamar untuk masing-masing jenis kamar adalah standard sebesar Rp. 172.249, superior sebesar Rp. 213.408, dan suite sebesar Rp. 331.182,--

Jika dibandingkan harga pokok kamar menurut Hotel Grand Bougenvill kota Bengkulu dengan metode Activity Based Costing System maka dapat dilihat harga pokok yang ditetapkan oleh Hotel Grand Bougenvill kota Bengkulu lebih rendah dari harga pokok yang dihitung menggunakan metode Activity Based Costing System. Selisih tersebut adalah standard sebesar Rp. 35.599,- superior sebesar Rp. 31.297,-, dan suite sebesar Rp. 57.881,-. Selisih ini disebabkan karena adanya pembebanan biaya overhead pada masing-masing jenis kamar. Pada perhitungan yang ditetapkan pihak manajemen Hotel Grand Bougenvill kota Bengkulu, biaya overhead tidak dimasukkan dalam perhitungan harga pokok kamar dan biaya-biaya yang terjadi pada masing-masing jenis kamar dibebankan pada satu jenis cost driver saja yang menyebabkan terjadinya distorsi biaya. Sedangkan pada penerapan Activity Based Costing System biaya overhead pada masing-masing produk dibebankan pada banyak cost driver sesuai dengan konsumsi aktivitas oleh produk atau jasa. Sehingga dalam penerapan Activity Based Costing System dapat mengalokasikan berbagai aktivitas biaya ke setiap tipe kamar secara tepat berdasarkan konsumsi masing-masing aktivitas.

Begitu juga dengan penetapan harga jual kamar, pada Hotel Grand Bougenville kota Bengkulu penentuan harga jual kamar hanya berdasrakan pada harga pasar saja, adapun harga jual kamar yang ditetapkan oleh Hotel Grand Bougenville kota Bengkulu yaitu standard sebesar Rp. 300.000,- superior sebesar Rp. 400.000,-, dan suite sebesar Rp. 600.000,. Jika menggunakan metode Activity Based Costing System dengan cara menambahkan mark up sebesar 25\%, PPN 10\% dan PPH Pasal 22 sebesar 1,5\% maka harga jual untuk masing-masing jenis kamar adalah standard sebesar Rp. 240.073,- superior sebesar Rp. 297.437,-, dan suite sebesar Rp. 461.585,.

Jika Hotel Grand Bougenville kota Bengkulu menetapkan harga jual kamar berdasarkan teori, maka Hotel Grand Bougenville kota Bengkulu telah mendapatkan keuntungan sebesar 25\%. Harga jual tersebut jauh lebih rendah dari harga pasar, sehingga akan memberikan keuntungan bagi pihak Hotel Grand 
Bougenville kota Bengkulu karena harga yang ditetapkan jauh lebih rendah dari harga pasar, sehingga para konsumen akan memilih Hotel Grand Bougenville kota Bengkulu jika ingin menginap.

\section{KESIMPULAN}

Berdasarkan hasil penelitian dan pembahasan yang dilakukan oleh penulis analisis activity based costing system dalam penentuan tarif kamar pada hotel Grand Bougenville Kota Bengkulu dapat ditarik kesimpulan bahwa:

1. Terdapat perbedaan antara harga pokok kamar yang ditentukan oleh pihak manajemen hotel Grand Bougenville Kota Bengkulu dan dengan penerapan Activity Based Costing System.

2. Hasil dari perhitungan harga pokok kamar dengan menggunakan Activity Based Costing Sytem yaitu, untuk kamar standard sebesar Rp. 172.249, superior sebesar Rp. 213.408, dan suite sebesar Rp. 331.182,-. Sedangkan harga pokok kamar berdasarkan perhitungan yang dilakukan oleh Hotel Grand Bougenvill kota Bengkulu diketahui untuk jenis kamar standard sebesar Rp. 136.651, superior sebesar Rp. 182.201, dan suite sebesar Rp. 273.302. Terdapat selisih perhitungan harga pokok kamar antara perhitungan Hotel Grand Bougenvill dengan metode Activity Based Costing Sytem yaitu standard sebesar Rp. 35.599,- superior sebesar Rp. 31.297,-, dan suite sebesar Rp. 57.881.

3. Perhitungan harga penjualan juga terdapat perbedaan antara perhitungan hotel Grand Bougenville Kota Bengkulu dengan hotel Grand Bougenville Kota Bengkulu dengan penambahan mark up sebesar $25 \%$ maka harga jual yang ditetapkan sebesar standard sebesar Rp. 240.073,- superior sebesar Rp. 297.437,-, dan suite sebesar Rp. 461.585,. Terdapat selisih harga yang lebih rendah antara penerapan harga manajemen hotel dengan hasil perhitungan menggunakan Activity Based Coting Sysem yaitu, standard sebesar Rp. 240.073,-- superior sebesar Rp. 297.437,-, dan suite sebesar Rp. 461.585,.

\section{SARAN}

Berdasarkan hasil penelitian dan kesimpulan, maka saran yang dapat disampaikan adalah:

1. Disarankan kepada pihak manajemen hotel Grand Bougenville Kota Bengkulu untuk melakukan perhitungan harga pokok kamar menggunakan metode Activity Based Costing karena perhitungannya lebih akurat.

2. Untuk penetapan harga jual disarankan untuk menggunakan mark up $25 \%$, karena harga yang ditetapkan jauh lebih rendah dari harga pasar, sedangkan hotel telah mendapatkan keuntungan sebesar 25\%. Sehingga konsumen akan memilih Hotel Grand Bougenville untuk menginap.

\section{DAFTAR PUSTAKA}

Anton, 2012. Analisis Penentuan Harga Pokok Produksi Mneggunakan Metode Activity Based Costing (Studi Kasus Pada Pt. Bintang Semarang) Vol.3 No. 3, September 2012

Kristanto Sofia Prima Dewi. Akuntansi Biaya. Penerbit IN MEDIA, 2013

Mulyadi, 2005. Akuntansi Biaya. Edisi Kelima. Yogyakarta: UPPAMP YKPN Universitas Gajah Mada

Mulyadi., 2013. Sistem Akuntansi, Edisi Ketiga, Cetakan Keempat, Salemba Empat, Jakarta.

R.A Supriyono, 2002. Akuntansu Manajemen I: Konsep Dasar Akuntansi Manajemen dan Perencanaan, edisis ketiga, Yogyakarta, BPFE

Sugiyono 2013. Metode Penenlitian Pendidikan Pendekatan Kuantitatif Kualitatif dan R\&D. Bandung: Alfabeta 